Sarıoğlu, M. \& Yıldırım, Ö. (2018). The effects of clustering new words in semantic, thematic or unrelated sets in teaching vocabulary to EFL learners. Abant İzzet Baysal Üniversitesi Ĕgitim Fakültesi Dergisi, 18 (2), 1064-1085.

\title{
THE EFFECTS OF CLUSTERING NEW WORDS IN SEMANTIC, THEMATIC OR UNRELATED SETS IN TEACHING VOCABULARY TO EFL LEARNERS
}

\author{
Mustafa SARIOĞLU* \\ Özgür YILDIRIM**
}

\begin{abstract}
Whether new vocabulary items should be taught in semantic, thematic or unrelated sets is a controversial issue in L2 lexical research. Although many studies suggest that presenting L2 words simultaneously in semantic sets has an interfering effect on the acquisition of those words, most of them have been conducted under strictly-controlled experimental conditions. Therefore, there is still a lack of classroom-based studies on this matter. With this in mind, this study aims to compare the effects of teaching new words in semantic, thematic and unrelated sets on EFL learners' acquisition of these words in a natural classroom setting. 18 participants were taught the real L2 target words in one of these three types of clustering through pictorial flashcards. They were also provided with a number of meaningful encounters with the target words in sentential contexts. The results showed that all of these three clustering types supplied EFL learners with very efficient recognition and production of the target vocabulary not only immediately after the treatment but also three weeks later. The study findings did not reveal any interfering effect of presenting and practicing semantically related words at the same time in real classroom conditions.
\end{abstract}

Key Words: clustering new words, vocabulary teaching, EFL

\section{YABANCI DİL EĞİTIMIINDE KELIMELERİN ANLAMSAL, TEMATIK VEYA BAĞLANTISIZ HÂLDE GRUPLANDIRILMASININ ÖĞRENMEYE OLAN ETKİSI}

\section{ÖZET}

Yabancı dil eğitiminde kelime öğretirken kelimelerin anlamsal, tematik ya da bağlantısız gruplar hâlinde öğretilmesi konusu hâlen tartışılmakta olan bir konudur. Öğretilecek kelimelerin aynı anda anlamsal olarak gruplandırılarak öğretilmesinin etkili olacağını öne süren pek çok çalışma olmasına rağmen bu çalışmalar genelde değişkenlerin kontrol altında tutulduğu deneysel çalışmalardır. Bu sebeple, sınıf içindeki doğal öğrenci davranışlarına odaklanan çalışmalara ihtiyaç duyulmaktadır. $\mathrm{Bu}$ çalışma da kelime ögretiminde kelimelerin anlamsal, tematik ya da bağlantısız gruplar hâlinde gruplanmasının öğrenme üzerindeki etkilerini doğal sınıf ortamında araştırmaktadır. Çalışmaya katılan 18 öğrenciye gerçek İngilizce kelimeler üç gruplama yönteminden biri kullanılarak öğretilmiştir. Çalışmanın sonuçları bütün gruplandırma yöntemlerinin kelime öğretimine katkısı olduğunu ortaya çıkarmıştır, fakat üç gruplandırma yönteminden herhangi birisinin diğerlerine göre daha etkili olduğu yönünde herhangi bir sonuca ulaşılamamıştır.

Anahtar Kelimeler: kelime öğretimi, kelimelerin gruplanması, İngilizce öğretimi

\footnotetext{
* Öğr. Gör., Bursa Technical University, School of Foreign Languages, msarioglu2007@gmail.com

** Doç. Dr.,Anadolu University, Faculty of Education, oyildirim@anadolu.edu.tr
} 


\section{INTRODUCTION}

Vocabulary plays an indispensable role in almost all stages of second language (L2) learning and teaching because a language is meaningless without its vocabulary. Firstly, a language is used as a means of communication, and words are essential for carrying out an effective verbal communication. As stated by Wilkins (1972), "Without grammar very little can be conveyed, without vocabulary nothing can be conveyed (p. 111)." Secondly, vocabulary knowledge is regarded as an indicator of overall L2 proficiency and as a facilitator of four main language skills. Sarığlu (2014) states that "if an analogy is made between a language and a human body, vocabulary is the heart which pumps blood to all the other vital organs such as reading, writing, listening and speaking" (p. 1). In this respect, a comprehensive L2 lexicon can be by far the most crucial facility with which L2 teachers can equip their students.

Despite the consensus on the significance of vocabulary instruction in L2 acquisition, there exists some controversy over the effectiveness of several vocabulary teaching principles. Particularly, whether new L2 vocabulary items should be taught in semantic sets, semantically unrelated sets or thematic sets is a matter of intense debate among the researchers in L2 lexical field (Ishii, 2015). Presenting vocabulary in semantic (lexical) sets means categorizing novel words systematically within meaningful sets, e.g., "colors", "animals", or "kitchen utensils" (Gairns \& Redman, 1986). In semantic clustering, a group of lexical items shares common semantic features, which is mainly based on a class membership (hyponymy). The semantically related words "shirt, jacket, skirt, coat," are all members (co-hyponyms) of the upper-class term "clothes". As for thematic clustering, it entails grouping new vocabulary items on the basis of a thematic concept. Tinkham (1997) exemplifies the thematic concept of "frog" with a set of words such as "green, pond, swim, slippery, hop" (p. 141). In this regard, thematic clustering provides an opportunity to teach words from different parts of speech at the same time. On the other hand, if lexical items are introduced in unrelated sets, they will have neither semantic nor thematic association with one another (see Figure 1).

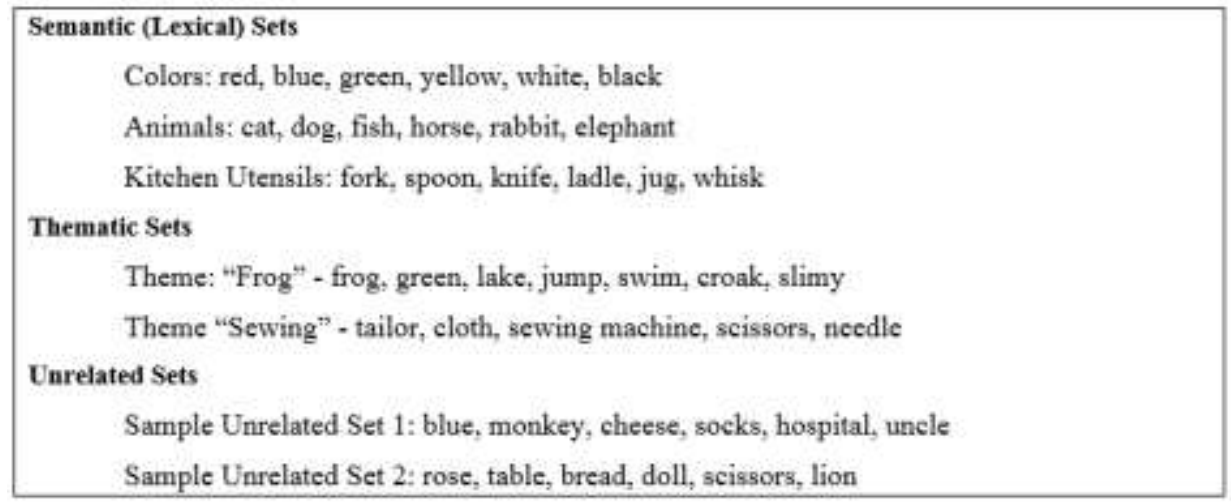

Figure 1: Clustering New L2 Words in Semantic, Thematic or Unrelated Sets 
The effects of clustering new words in semantic, thematic or unrelated sets in teaching...

Some studies support the common teaching practice of grouping semantically related words together as an effective way of teaching new L2 vocabulary items (e.g., Gairns \& Redman, 1986; Graves, 2006; Hashemi \& Gowdasiaei, 2005; Haycraft, 1993; Hoshino, 2010; McCarthy, 1990; Stahl \& Naggy, 2006). According to this view, if L2 words sharing common semantic elements are presented within the same lexical set, it will facilitate the acquisition of the given words by L2 learners. This standpoint is based on the familiar psychological principle that it is easier to learn well-organized information than unorganized one (Baddeley, 1990). Such grouping is regarded to comply with organization of semantic fields in human brain (Aitchison, 1994). Therefore, it will be easy to recall semantically related words from memory as they are stored in the brain in a similar fashion (Nation, 2000). In this regard, many current language curriculum and textbooks tend to present novel L2 words in semantic clusters.

On the other hand, some other lexical research is in favor of teaching lexical items in semantically unrelated sets (e.g., Erten \&Tekin, 2008; Finkbeiner \& Nicol, 2003; Nation, 2000; Tinkham, 1993; Waring, 1997). An increasing number of studies suggest that presenting L2 learners with semantically related words at the same time will hamper the acquisition of these lexical items, which is a matter of confusion in learning. This viewpoint proposes "interference theory" of human mind as a rationale for opposition to present new words in semantic sets (Tinkham, 1997). According to this theory, if a new item to be learned has got too many similarities with those learned just beforehand, it will be more difficult to learn the given item due to interference effects of these similar words on each other. As an example, the words "right" and "left" are generally confused by L2 learners in that they are too similar and share the same semantic features except "direction" (Schmitt, 2000). Hence, an overwhelming amount of research evidence strongly highlights that teaching of L2 words simultaneously in semantic sets has an interfering effect on learning of these lexical items.

Tinkham (1997) has proposed thematic clustering as an alternative way of lexical grouping, in which new L2 words are organized around one theme. The results of his study have revealed positive evidence about the facilitative role of thematic clustering on learning new L2 vocabulary items as compared to semantic clustering. A few subsequent studies have also confirmed Tinkham's research findings by highlighting the positive effect of grouping novel words in thematic sets (e.g., Al-Jabri, 2005). The related literature also includes some research evidence which has revealed no statistically significant difference between thematic and semantic clustering of L2 words (e.g., Hippner-Page, 2000). In this regard, Hedge (2000) insists that learners will still come up against the interference effect even when L2 vocabulary items are presented in thematic sets.

In conclusion, there is no consensus among the studies in the relevant L2 lexical research. Some studies are in favor of semantic or thematic clustering of new vocabulary items whereas some others repeatedly argue that related words should not be taught at the same time due to the interfering effect. Given this controversy, this issue is still worthy of further investigation, especially through more authentic classroom-based research studies. Therefore, the current study aims to investigate the effects of presenting new words in semantic, thematic, and unrelated sets on vocabulary acquisition of EFL learners in a real classroom setting. It specifically tries to compare these three types of grouping L2 target words with regard to EFL learners' recognition and recall of these lexical items 
after they were provided with some meaningful encounters with the target words in sentential contexts. Thus, this study attempts to answer the following two research questions:

1- What are the effects of presenting new L2 words in semantic, thematic, and unrelated sets in terms of EFL learners' immediate or delayed recognition and production of these vocabulary items?

2- Does presenting new L2 words in semantic, thematic, or unrelated sets differ in terms of EFL learners' immediate or delayed recognition and production of these vocabulary items?

\section{LITERATURE REVIEW}

\subsection{Research in Favor of Presenting Words in Semantic Sets}

The relevant literature comprises some studies which are still in favor of teaching new L2 words in semantic sets because it offers well-organized information to L2 learners. As an example, Hashemi and Gowdasiaei (2005) analyzed the effectiveness of teaching vocabulary in semantic sets versus semantically unrelated sets regarding both vocabulary size and depth. The study findings showed that the participants taught words in semantic set achieved greater gains in both their vocabulary depth and breadth than those taught the same words in unrelated set. Hoshino (2010) also conducted a study to find out what type of word lists are more effective means to learn L2 vocabulary items for different types of learners: 1) synonyms, 2) antonyms, 3) categorical/semantic, 4) thematic, and 5) unrelated. The results demonstrated that all the learners with different learning styles memorized the target words in the categorical list better than those items in the other four lists. Hence, these studies revealed a positive research evidence for arranging novel L2 words in semantically related sets.

Tinkham (1997) puts forward two motivations driving the viewpoint of presenting new L2 words in semantic sets. First, semantic clustering seems to be convenient for both of two distinct methodologies in L2 teaching. Beyond structure-based methods, more learner-centered communicative approaches also adopt semantic grouping mostly to serve new words. Second, grouping words in relation to their semantic features is believed to help learners explore the semantic boundaries among the concepts of words in the set (Gairns \& Redman, 1986). That is, presenting semantically related words simultaneously is regarded to offer useful framework for L2 learners to realize semantic similarities and differences among these words.

McCarthy (1990) mentions the benefits of using word associations in teaching vocabulary. Seeing that words are semantically organized and stored in brain, learners are regarded to recall words more easily based on these semantic and conceptual mapping (Aitchison, 1994). Therefore, teaching words in semantic set is thought to be compatible with the efficient organization of semantic fields in our brain. Likewise, Haycraft (1993) makes an analogy between introducing words in unrelated sets and a tree with no trunk and branches but only leaves. Briefly, these studies provide L 2 teachers with pedagogical implication that they should systematically arrange and teach the new L2 words in meaningful sets. 
The effects of clustering new words in semantic, thematic or unrelated sets in teaching...

\subsection{Research Supporting Unrelated or Thematic Clustering of New Words}

The literature also includes an increasing number of studies which support presenting novel L2 words in unrelated sets due to the interfering effect of semantic grouping (e.g., Erten \& Tekin, 2008; Finkbeiner \& Nicol, 2003; Tinkham, 1993; Waring, 1997). Tinkham (1993) carried out two experiments to compare the vocabulary learning rates of the participants in both semantic and unrelated sets. The results indicated that target words could be learned faster and with fewer trials through unrelated groupings as compared to semantic clustering. In his replication study, Waring (1997) verified that learning the semantically related words required more learning trials and longer time than the unrelated ones. Finkbeiner and Nicol (2003) also investigated the vocabulary recall of the learners who were presented with new words in either semantic or unrelated sets. The results revealed that the recall of vocabulary items taught in semantic sets was quite slower than those introduced in unrelated sets. Erten and Tekin (2008) compared introducing words in semantic versus unrelated sets in terms of both immediate and delayed recall as well as test completion time. The study findings indicate that presenting words in unrelated sets produced greater vocabulary gain and recall than learning the same words in semantic sets. Test completion time was also much longer for those learning the words in semantic sets. In brief, these studies argued that it was more advantageous to teach words in semantically-unrelated sets.

Some other studies suggest thematic grouping as an alternative way to semantic sets by highlighting the facilitative effect of thematic clustering on learning new vocabulary items (e.g., Al-Jabri, 2005; Tinkham, 1997). Tinkham (1997) proposed thematic clustering as an alternative way of presenting L2 vocabulary items. He conducted two experiments to compare the effects of presenting new words in semantic, thematic and unrelated sets on L2 learners' acquisition of these vocabulary items. The results demonstrated that the participants made a greater number of trials to learn semantically related words than unrelated words. Moreover, thematically related words were learned more easily than semantically related words. The thematic grouping was revealed to be more helpful for lexical learning compared to the unrelated sets both in recognition and recall tests. Al-Jabri (2005) also investigated the effects of presenting new vocabulary in four types of clusters: 1) semantic, 2) unrelated, 3) thematic, and 4) contextual. The study results showed that unrelated and thematic clustering are more effective means for learning L2 vocabulary items. These two were followed by semantic and contextual clustering, respectively. However, these four lexical groupings revealed no statistically significant differences among advanced L2 learners.

The related literature also includes several studies, the results of which could not differentiate among various types of clustering. As an example, a study by Hippner-Page (2000) found no statistically significant difference between thematic and semantic clustering of L2 words. Similarly, Ishii $(2013,2015)$ observed no significant difference between semantic and unrelated sets. She suggested that learning semantically related words neither more difficult nor easier for students than learning them in unrelated sets. Furthermore, the findings of some other studies varied according to different variables. Mirjalali, Jabbari and Rezai (2012) conducted a study to compare the effects of thematic and semantic grouping on L2 learners' acquisition of new words both in isolation and in context. The results demonstrated the superiority of unrelated clustering when the participants learned the target words in isolation. On the other hand, thematic grouping 
was shown to be more effective when they learned the new words in context. Papathanasiou (2009) found out the interfering effect of semantic grouping only for adult beginners, but not for young intermediate L2 learners.

Although there exists more research evidence on the interfering effect of semantic clustering, most of these studies are not natural enough to draw conclusions about vocabulary acquisition of learners in real L2 classrooms. In these studies:

a) The participants are usually expected to memorize the target words in a restricted time (e.g., Finkbeiner \& Nicol, 2003; Ishii, 2013, 2015; Tinkham, 1993, 1997; Waring, 1997; Wilcox \& Medina, 2013).

b) Artificial words (pseudo-words) are mostly selected as target words, rather than real L2 words (e.g., Finkbeiner \& Nicol, 2003; Ishii, 2013, 2015; Tinkham, 1993, 1997; Waring, 1997).

c) The target items are usually taught in isolation instead of being presented within a larger context, and the participants are not provided with an opportunity to practise newly-learned vocabulary items (e.g., Erten \& Tekin, 2008; Finkbeiner \& Nicol, 2003; Ishii, 2013, 2015; Tinkham, 1993, 1997; Waring, 1997).

All in all, the majority of studies in the related literature seem to have been carried out under strictly-controlled experimental conditions. With this in mind, there is still a lack of real classroom-based studies to investigate the effects of semantic, thematic, or unrelated clustering of new L2 vocabulary items. As an example, Bolger and Zapata (2011) revealed that the adding story context to L2 words seems to overcome the disadvantages of learning vocabulary in semantic sets. Thus, there is a need to know more about how the results would be if the L2 learners studied the words in real classroom situations and practiced them in a larger context and within a great deal of time, which is the main motivation behind the present study.

\section{METHODOLOGY}

\subsection{Participants}

18 Turkish EFL learners participated in the study. The participants were eleventh-grade students from an intact class at a state high school in the city of Bursa, Turkey. Ten of the participants were males, and eight of them were females. Their ages ranged from 15 to 16. The participants were native speakers of Turkish. They were all EFL learners at A2 CEFR (Common European Framework of Reference for Languages) level. The participants were all supposed to have similar educational background since they had been enrolled in the given school through the same nation-wide proficiency exam over two years before the study was conducted.

The treatments for the study were carried out in participants' natural classroom setting. The participants received the vocabulary instruction as they usually did within their course. Their teacher had 11 years of experience in teaching English as a foreign language. All the treatments were carried out by this teacher in order to rule out the variations in teaching procedure.

Non-probability convenience sampling method was employed in the selection of the participants. Although there had been 23 participants at the beginning, five participants were excluded at the analysis stage in view of their pre-test results, which showed that 
The effects of clustering new words in semantic, thematic or unrelated sets in teaching...

they had already known 2 or 3 of the target words prior the study. Thus, the data from 18 participants who took 0 in the pre-test were included into the statistical analyses.

\subsection{Setting}

The study was carried out in a natural classroom setting at a public high school in the central district of Bursa, Turkey. Five EFL teachers were working in the given school. There were six eleventh-grade classes, and totally 4 hours of English course were allocated to each of these classes per week. There were two main reasons why this particular school was selected as the research site. First, one of the researchers had been working as an EFL teacher here for 6 years when this study was conducted. This would not only facilitate the planning and implementation of the current research but also ensure natural group dynamics since the researcher was the teacher of this intact class. Second, the school registered students from a neighborhood where middle-class working people lived. Obviously, working with such a homogenous group of participants would reduce possible individual variations.

\subsection{Research Design}

This study employed one group quasi-experimental research model in pre-post test design with repeated measures. Data were collected during 2016-2017 academic year. Initially, verbal informed consent was obtained from all of the participants as well as the principal of the given school. Prior to the treatments, the participants were pre-tested about their prior knowledge of the target words. Three experimental treatments were conducted in natural classroom setting. In the first treatment, all the participants were taught each of six target English words in unrelated sets. Each target concrete noun was instructed through pictorial flashcards along with sentential contexts, in which three example sentences were provided to the participants. Immediately after the treatment, the participants took immediate post-tests in two modalities: one for word recognition and the other for word production. In the second and third treatments, the participants were presented with the other target words in semantic and thematic sets, respectively. All the treatments were completely the same, except for the target words. They entailed the use of exactly the same teaching materials (pictorial flashcards) in the same amount of time (30 minutes for each treatment) and by means of the same technology (PowerPoint slides). The delayed post-tests were administered three weeks after the treatment in order to measure the participants' delayed recognition and production of the target words.

\subsection{Target Words}

In the relevant literature, most of the studies selected pseudo-words (artificial words) as target words (e.g., Finkbeiner \& Nicol, 2003; Ishii, 2013, 2015; Tinkham, 1993, 1997; Waring, 1997). However, eighteen real English words were assigned as target vocabulary items in the current study (see Table 1). Six of them were semantically related, six were thematically related, and the remaining six were unrelated words. The target lexical items in each set were homogenous in terms of their size, type and length. As a part of speech, each set included concrete nouns. Initially, in order to identify the suitable frequency bands for the target words, the reading texts in the textbook (Baydar Ertopçu et. al, 2014) used by the given state school were put through Cobb's vocabulary profiler (Cobb, n.d.). The scores suggested that the students read the texts which included English words from 
the 1,000 and 2,000-word level. With this in mind, the frequency bands of each word were checked from Nation's Vocabulary Levels (Appendix 3 in Nation, 2001, pp. 416424). Then, 24 candidates for target words were identified from 5,000-word level and above, which were not likely to be known by the participants. The final decision on 18 target words was taken through the feedback from 3 EFL teachers, one of whom was working in the given state school. Thus, it is reasonable to assert that the target words in each set were also homogenous in terms of their frequency bands.

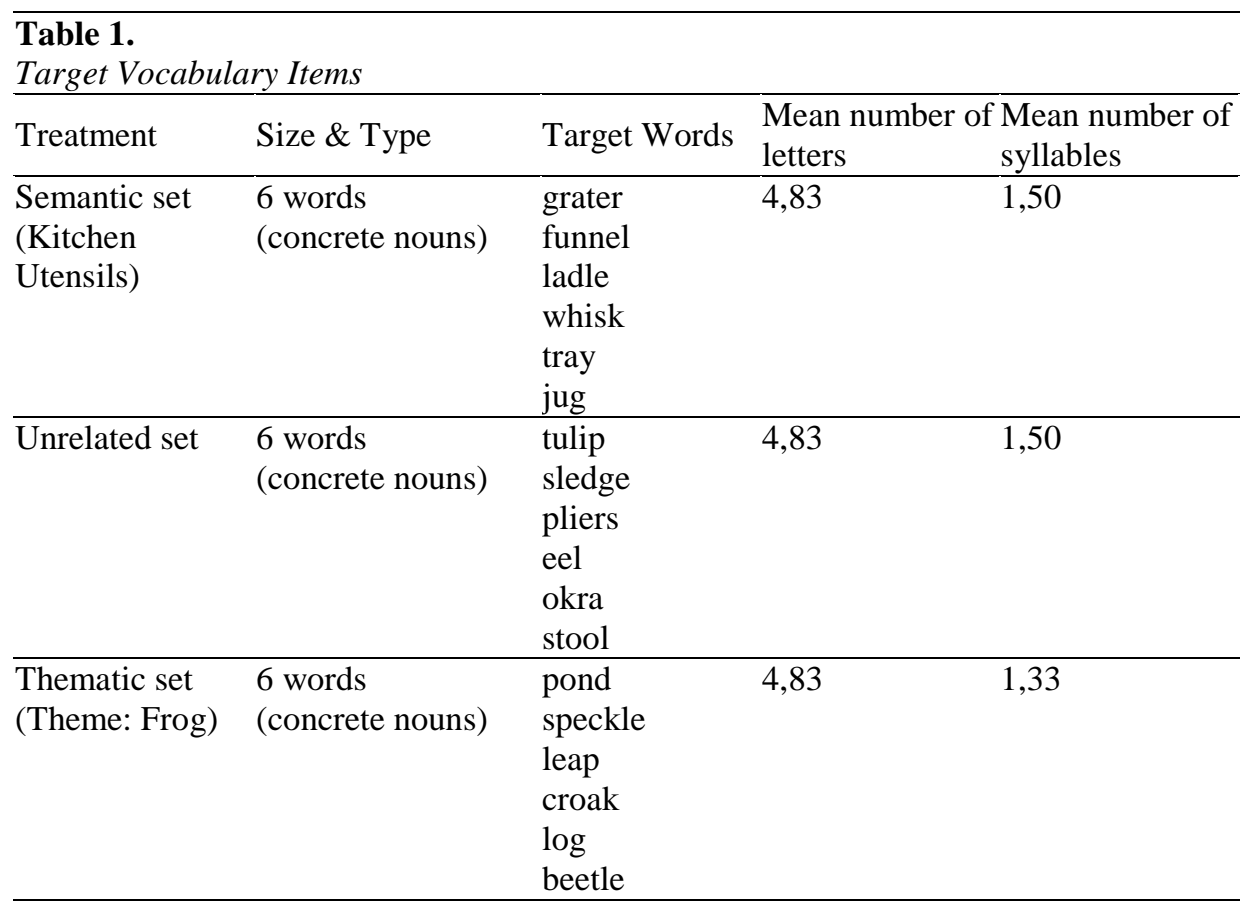

\subsection{Instructional Materials}

All vocabulary instruction was given through a PowerPoint presentation, which includes pictorial flashcards not only for teaching the target words but also for practicing them in sentential contexts. Three different types of pictorial flashcards were prepared to present each of 18 target items to the participants (see Figure 2). One of these flashcards included only the picture related to the corresponding word in order to establish a context which leads learners to the meaning of the given word. In these cards, there are no English spellings of the words under the pictures so that learners can guess the meaning themselves in the pre-teaching and the practice stages. In the second flashcards, the pictures of the target words were accompanied with their English labels and parts of speech underneath. The last types of flashcards were prepared so that the participants could practice each target item in three different sentential contexts. Here the sample sentences were embedded in the corresponding pictures. All the pictorial flashcards were prepared in big sizes so that even those students sitting at the back side of the classroom could see them easily. 

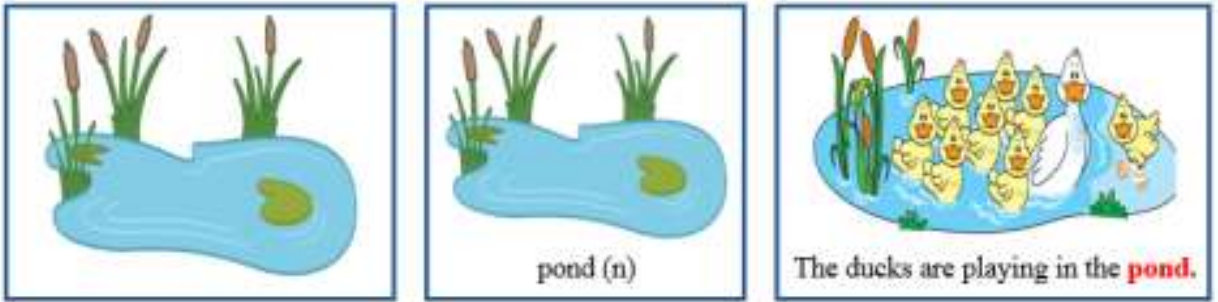

Figure 2: Sample pictorial flashcards for teaching the English word "pond"

\subsection{Testing Instruments for Data Collection}

Three kinds of testing instruments were developed as data collection tools of the present study: (a) the pre-test, (b) the immediate post-tests, and (c) the delayed post-tests.

The pre-test was in the 6-option multiple choice format designed to test the participants' recognition of the target words. The participants had to choose the English equivalents of the target words with the help of the pictures given as clues above the options (see Figure 3). The choice "I don't know" was also added to the pre-test items as a seventh option in order to prevent the participants from inflating their scores by guessing. The pre-test items were embedded within another routine-classroom activity to distract participants' attention from the target words.

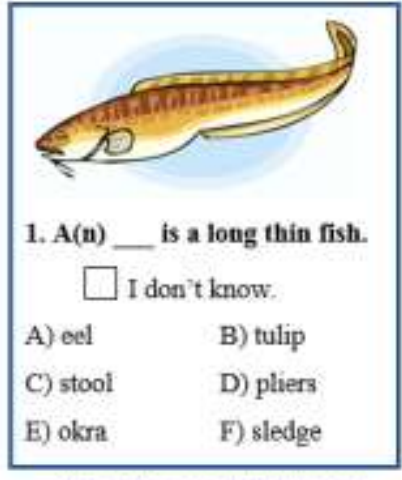

Figure 3: A sample pre-test item

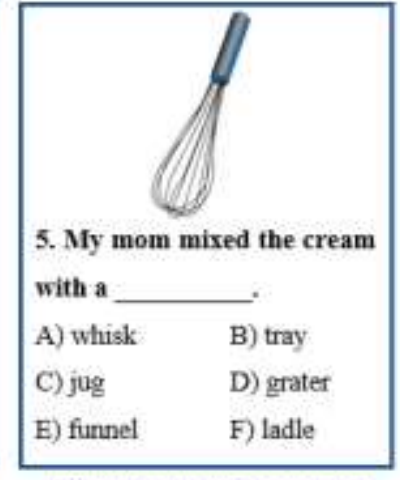

Figure 4: A sample post-test izem (word recognition)

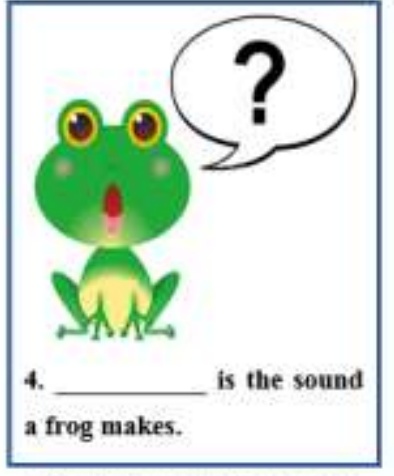

Figure 5: A sample post-test item (word prodiction)

The immediate and delayed post-tests were conducted in two modalities in order to measure both the participants' recognition (L2-L1) and production (L1-L2) of target words. The word-recognition tests were in the 6-option multiple-choice format, where participants had to choose the English equivalents of the target words with the help of the pictures given as clues above the options (see Figure 4). In the word-production tests, the corresponding pictures were accompanied with the example sentences of the target words, and the participants were asked to produce (write) L2 equivalents of the target words into the blanks within these sentences (see Figure 5).

Totally, six immediate post-tests were administered without prior notice to the participants. Three types of immediate-post-tests (one for the semantic set, one for thematic set, and the other for unrelated set) were administered in two modalities (one 
for word recognition and the other for word production). Each post-test included six lexical items. The same tests were repeated three weeks later as delayed post-test. The forms of the immediate post-tests were not exactly the same as those of the delayed posttests. The order of the test items and the arrangement of the options were completely different in all tests. These changes were made to eliminate the possibility that the students would recall the right answers from their pictorial memory.

\subsection{Instructional Procedure}

The participants' prior knowledge of the target words were measured through a pre-test before the treatments were carried out. After the pre-test, all the participants were initially taught the target words in each set (unrelated, semantic, and thematic) through pictorial flashcards. Then, they practiced each word in three different sentential contexts which were also accompanied by visual images. The participants received the same amount of instruction on each set of target words. They were taught by the same instructor with the same amount of teaching materials.

Instructional procedure for each target word was as follows: First, the teacher showed the unlabeled pictorial flashcard to establish a context for teaching the target word (see Figure 6). Here the teacher asked the students some questions in order to lead them to the meaning of the given word in L1. When the participants guessed the meaning of the word in L1 correctly, the teacher pronounced the target English word three times: "grater", "grater", and "grater". Afterwards, the participants were shown the labeled pictorial flashcard (see Figure 7). Seeing the spelling of the target item on the slide show, the participants repeated the pronunciation of the word three times after the teacher. Meanwhile, they also saw the L1 equivalent of the target word on the slide show. Then, the participants were provided with three example sentences along with the corresponding picture (see Figure 8) in order to practice the newly-learned target items. In this phase, the teacher read and checked the participants' comprehension of these sample sentences.
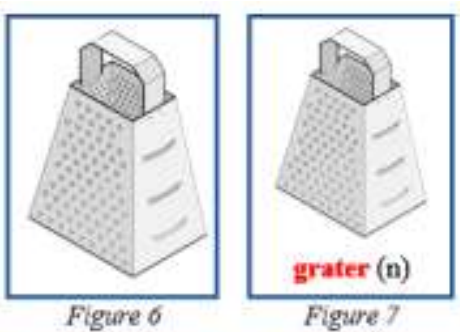

Figure 7

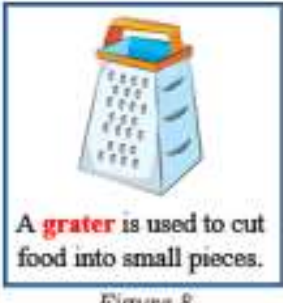

Figure 8

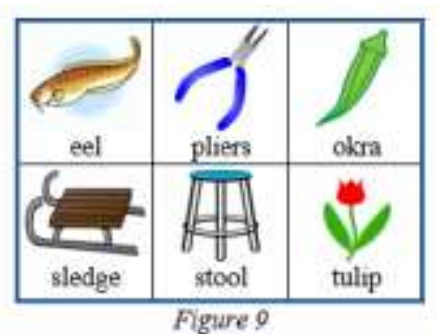

When all of 6 target words were individually instructed in the same way, all the words in the set and their visual representations were shown to the participants for the last time (see Figure 9). Once again, the teacher pronounced each target word three times and the participants were asked to repeat after him. Finally, all the target words were practiced in the classroom through a simple activity. Within this activity, the teacher showed the unlabeled pictorial flashcards of each target item only once, and the participants guessed and produced orally the given target word in L2 as a whole class. The vocabulary instruction and practice for each set of the words lasted about 20 minutes. 
The effects of clustering new words in semantic, thematic or unrelated sets in teaching...

After 5-minute distraction activity, the immediate post-tests were administered in two modalities. Initially, the participants were given the word production tests to measure their productive knowledge (active recall) of the target items. Then, their recognition of the target words was checked through another immediate post-test in the multiple-choice format. In view of the number of the items to be answered, 5 minutes were devoted to the administration of each immediate post-test, but the participants completed these tests in shorter time. The whole experimental treatment for one set of the words lasted about 30 minutes. The remaining two sets of the words were instructed and tested in another two successive 30-minute sessions. After a three-week interval, six post-tests were repeated in order to check the participants' delayed recognition and recall of the target words in each set. Once again, the participants were given 5 minutes to complete each of six delayed post-tests.

\subsection{Data Collection and Analysis}

The pre-test, immediate post-tests and delayed post-tests were used as data collection tools. Rather than measuring the participants' prior knowledge of the target vocabulary, the pre-tests were mainly used to eliminate those who had already known some of the target words. On the basis of their scores on the pre-tests, the data from 5 participants were excluded at the analysis stage.

In scoring of word-production tests, 1 point was given for each completely produced target word, and 0.5 point was assigned for the responses with one spelling mistake. The answers with more mistakes were not accepted as true. In scoring of word-recognition tests, 1 point was given for each correct answer. Possible maximum score for all tests was 6.00 .

As for the reliability and validity of the study, all the instructional materials and instruments for data collection were reviewed and checked by 3 EFL teachers, who were also $\mathrm{Ph} . \mathrm{D}$. students at a university. In addition, all the treatments and tests were piloted with five volunteer $10^{\text {th }}$ grade students in the same school. During the pilot study, the treatments were also timed. Furthermore, Cronbach's Alpha analysis was run to measure the internal reliability of the testing instruments. The reliability co-efficient was 0.783 for 12 items, which indicates an acceptable internal consistency $(\alpha>0.700)$.

For analyzing the data, initially, descriptive statistics (mean scores, standard deviations) were calculated for each type of treatment. Next, after ensuring that the normality assumption was met, one-way repeated measures ANOVA analyses were conducted to find out the impact of clustering new L2 words in semantic, thematic, or unrelated sets on EFL learners' recognition and production of these vocabulary items and to find out whether the type of lexical clustering (unrelated, semantic, and thematic) has an effect on EFL learners' recognition and production of the target vocabulary items. Pair-wise comparisons with Bonferroni adjustment were also conducted as post hoc tests for statistically significant differences. 


\section{RESULTS}

The research findings will be explained in detail hereafter in the light of two research questions. The first research question of the study was as follows: "What are the effects of presenting new L2 words in semantic, thematic, and unrelated set in terms of EFL learners' immediate or delayed recognition and production of these vocabulary items?"

One-way repeated measures ANOVA analyses were employed to statistically verify the facilitative effects of teaching new L2 words in semantic, thematic, or unrelated set on EFL learners' recognition and production of these target items. For each type of lexical clustering, these analyses revealed statistically significant differences among vocabulary gain scores of the participants before and after the treatments. In this regard, all the related analyses and statistics demonstrated that all three types of clustering provided EFL learners with vocabulary gains (see Tables 2, 3, and 4).

\subsection{Semantic Clustering}

Table 2 shows that teaching new words in semantic sets was found to have a statistically significant effect on EFL learners' recognition of the target words, $F(2,34)=6057.919$, $\mathrm{p}<0.001$. Pair-wise comparisons were conducted as post hoc tests, and they supported the significant differences between the pre-test and the immediate post-test mean scores of the participants $(\mathrm{M}=5.94, \mathrm{SD}=0.24)$ as well as between the pre-test and the delayed post-test scores $(\mathrm{M}=5.06, \mathrm{SD}=1.26)$ at $\mathrm{p}<0.001$ level. The semantic grouping also provided EFL learners with significantly higher vocabulary production scores, $F(2,34)$ $=269.112, \mathrm{p}<0.001$. This facilitative effect was verified through the pair-wise comparisons, which revealed statistically significant differences not only between the pre-test and the immediate post-test scores $(\mathrm{M}=5.53, \mathrm{SD}=0.74)$ but also between the pre-test and the delayed post-tests $(\mathrm{M}=1.39, \mathrm{SD}=1.09)$ at $\mathrm{p}<0.001$ level. In the light of these findings, it can be concluded that the presenting new words in semantic sets had a beneficial effect on EFL learners' recognition and production of the target words.

Table 2.

The effect of semantic clustering on EFL learners' vocabulary learning

\begin{tabular}{|c|c|c|c|c|c|c|c|}
\hline & & $\mathrm{N}$ & M & SD & df & $\mathrm{F}$ & $\mathrm{p}$ \\
\hline \multirow{3}{*}{$\begin{array}{c}\text { Word } \\
\text { Recognition }\end{array}$} & Pre-test & 18 & 0.00 & 0.00 & \multirow{3}{*}{$\begin{array}{c}2 \\
34\end{array}$} & \multirow{3}{*}{6057.919} & \multirow{3}{*}{0.000} \\
\hline & Immediate post-test & 18 & 5.94 & 0.24 & & & \\
\hline & Delayed post-test & 18 & 5.06 & 1.26 & & & \\
\hline \multirow{3}{*}{$\begin{array}{c}\text { Word } \\
\text { Production }\end{array}$} & Pre-test & 18 & 0.00 & 0.00 & \multirow{3}{*}{$\begin{array}{c}2 \\
34\end{array}$} & \multirow{3}{*}{269.112} & \multirow{3}{*}{0.000} \\
\hline & Immediate post-test & 18 & 5.53 & 0.74 & & & \\
\hline & Delayed post-test & 18 & 1.39 & 1.09 & & & \\
\hline
\end{tabular}

Maximum mean score $=6.00$

\subsection{Thematic Clustering}

Table 3 reveals that presenting new words in thematic sets were also found to be statistically advantageous in terms of EFL learners' recognition of these words, $F(2,34)$ $=363.044, \mathrm{p}<0.001$. Pair-wise comparisons highlighted the significant difference between the pre-test and the immediate post-test mean scores $(\mathrm{M}=6.00)$ as well as between the pre-test and the delayed post-test $(\mathrm{M}=5.17, \mathrm{SD}=1.15)$ at $\mathrm{p}<0.001$ 
The effects of clustering new words in semantic, thematic or unrelated sets in teaching...

significance level. The analysis also showed that the participants got significantly high vocabulary production gains through thematic clustering, $F(2,34)=1000.662$, p $<0.001$. The significance of difference was also confirmed by pair-wise comparisons not only between the pre-test and the immediate post-test $(\mathrm{M}=5.69, \mathrm{SD}=0.55)$ but also between the pre-test and the delayed post-test mean scores of the participants $(\mathrm{M}=2.08, \mathrm{SD}=$ $1.83)$ at $\mathrm{p}<0.001$ level. Hence, the results suggested that thematic grouping of new words were significantly effective in providing EFL learners with higher word recognition and word production scores.

Table 3.

The effect of thematic clustering on EFL learners' vocabulary learning

\begin{tabular}{|c|c|c|c|c|c|c|c|}
\hline & & $\mathrm{N}$ & $\mathrm{M}$ & SD & $\mathrm{df}$ & $\mathrm{F}$ & $\mathrm{p}$ \\
\hline \multirow{3}{*}{$\begin{array}{c}\text { Word } \\
\text { Recognition }\end{array}$} & Pre-test & 18 & 0.00 & 0.00 & \multirow{3}{*}{$\begin{array}{c}2 \\
34\end{array}$} & \multirow{3}{*}{363.044} & \multirow{3}{*}{0.000} \\
\hline & Immediate post-test & 18 & 6.00 & 0.00 & & & \\
\hline & Delayed post-test & 18 & 5.17 & 1.15 & & & \\
\hline \multirow{3}{*}{$\begin{array}{c}\text { Word } \\
\text { Production }\end{array}$} & Pre-test & 18 & 0.00 & 0.00 & \multirow{3}{*}{$\begin{array}{c}2 \\
34\end{array}$} & \multirow{3}{*}{1000,662} & \multirow{3}{*}{0.000} \\
\hline & Immediate post-test & 18 & 5.69 & 0.55 & & & \\
\hline & Delayed post-test & 18 & 2.08 & 1.83 & & & \\
\hline
\end{tabular}

Maximum mean score $=6.00$

\subsection{Unrelated Clustering}

The results presented in Table 4 show that the participants also gained significantly high vocabulary recognition scores with the help of unrelated clustering, $F(2,34)=2422.720$, $\mathrm{p}<0.001]$. Pair-wise comparisons verified the significance of the differences between the pre-test and immediate post-test $(\mathrm{M}=5.89, \mathrm{SD}=0.47)$ as well as between the pretest and delayed post-test mean scores of participants $(\mathrm{M}=5.67, \mathrm{SD}=0.59)$ at $\mathrm{p}<0.001$ level. Furthermore, the findings also yielded statistically significant difference among three administrations of the word production tests conducted in unrelated sets, $F(2,34)=$ 657.167, $\mathrm{p}<0.001$. The pair-wise comparisons justified the statistically significant difference not only between the pre-test and the immediate post-test scores $(\mathrm{M}=5.53$, $\mathrm{SD}=0.67)$ but also between the pre-test and the delayed post-tests $(\mathrm{M}=1.94, \mathrm{SD}=$ $1.48)$ at $\mathrm{p}<0.001$ level. Thus, these results revealed positive research evidence about the facilitative effect of clustering new L2 words in unrelated sets on EFL learners' recognition and recall of these words.

Table 4.

The effect of unrelated clustering on EFL learners'vocabulary learning

\begin{tabular}{|c|c|c|c|c|c|c|c|}
\hline & & $\mathrm{N}$ & M & SD & df & $\mathrm{F}$ & $\mathrm{p}$ \\
\hline \multirow{3}{*}{$\begin{array}{c}\text { Word } \\
\text { Recognition }\end{array}$} & Pre-test & 18 & 0.00 & 0.00 & \multirow{3}{*}{$\begin{array}{c}2 \\
34\end{array}$} & \multirow{3}{*}{2422.720} & \multirow{3}{*}{0.000} \\
\hline & Immediate post-test & 18 & 5.89 & 0.47 & & & \\
\hline & Delayed post-test & 18 & 5.67 & 0.59 & & & \\
\hline \multirow{3}{*}{$\begin{array}{c}\text { Word } \\
\text { Production }\end{array}$} & Pre-test & 18 & 0.00 & 0.00 & \multirow{3}{*}{$\begin{array}{c}2 \\
34\end{array}$} & \multirow{3}{*}{657.167} & \multirow{3}{*}{0.000} \\
\hline & Immediate post-test & 18 & 5.53 & 0.67 & & & \\
\hline & Delayed post-test & 18 & 1.94 & 1.48 & & & \\
\hline
\end{tabular}

Maximum mean score $=6.00$ 


\subsection{The Effect of Clustering in Immediate Recognition and Production}

The second research question of the study was as follows: "Does presenting new L2 words in semantic, thematic, or unrelated sets differ in terms of EFL learners' immediate or delayed recognition and production of these vocabulary items?". Table 5 presents the results of data analysis related to immediate post-test part of the second research question. Although each type of clustering was found to result in superior vocabulary learning, there was no statistically significant difference across teaching L2 words in semantic, thematic, or unrelated sets in relation to participants' immediate recognition of the target words, $F(2,34)=0.600, \mathrm{p}=0.553$. Results also indicate that there was no statistically significant difference among three types of clustering with regard to participants' immediate production of the target vocabulary items, $F(2,34)=0.386, \mathrm{p}=0.682$.

In brief, the findings of the immediate post-tests pointed out that teaching L2 words in semantic, thematic, and unrelated sets all led to higher vocabulary gains for EFL learners. In all types of lexical grouping, the participants gained equally well regarding both immediate recognition and production of the target words. Hence, the findings of this study have not revealed any interfering effect for any of these three clustering types on EFL learners' immediate recognition and production of target words in a real L2 classroom.

Table 5.

The results of the immediate post-tests

\begin{tabular}{|c|c|c|c|c|c|c|c|}
\hline & & $\mathrm{N}$ & $\mathrm{M}$ & SD & $\mathrm{df}$ & $F$ & $p$ \\
\hline \multirow{3}{*}{$\begin{array}{l}\text { Immediate post-test } \\
\text { (Word Recognition) }\end{array}$} & Semantic Set & 18 & 5.94 & 0.24 & \multirow{3}{*}{$\begin{array}{c}2 \\
34\end{array}$} & \multirow{3}{*}{0.600} & \multirow{3}{*}{0.553} \\
\hline & Thematic Set & 18 & 6.00 & 0.00 & & & \\
\hline & Unrelated Set & 18 & 5.89 & 0.47 & & & \\
\hline \multirow{3}{*}{$\begin{array}{l}\text { Immediate post-test } \\
\text { (Word Production) }\end{array}$} & Semantic Set & 18 & 5.53 & 0.74 & \multirow{3}{*}{$\begin{array}{c}2 \\
34\end{array}$} & \multirow{3}{*}{0.386} & \multirow{3}{*}{0.682} \\
\hline & Thematic Set & 18 & 5.69 & 0.55 & & & \\
\hline & Unrelated Set & 18 & 5.53 & 0.67 & & & \\
\hline
\end{tabular}

Maximum mean score $=6.00$

\subsection{The Effect of Clustering in Delayed Recognition and Production}

Table 6 presents the results of data analysis related to delayed post-test part of the second research question. The table indicates that the participants' receptive gains from the treatments were quite stable even three weeks later although the target words were not revised in the class during this time. Although presenting new L2 words in unrelated sets resulted a slightly higher word recognition mean score than the other two sets, these results again revealed no statistically significant difference across these three methods of grouping new vocabulary items, $F(2,34)=1.755, \mathrm{p}=0.183$. Similarly, considering the delayed post-tests of word production, although presenting the target words in thematic set seemed a bit advantageous, this difference was not found to be statistically significant across the three methods of grouping new vocabulary items, $F(2,34)=1.084, \mathrm{p}=0.346$. To conclude, the findings of this study have not revealed any interfering effect for any of the three clustering types on EFL learners' delayed recognition and production of target words. 
The effects of clustering new words in semantic, thematic or unrelated sets in teaching...

\begin{tabular}{|c|c|c|c|c|c|c|c|}
\hline \multicolumn{8}{|c|}{$\begin{array}{l}\text { Table } 6 . \\
\text { The results of the delayed post-tests }\end{array}$} \\
\hline & & $\mathrm{N}$ & $\mathrm{M}$ & $\mathrm{SD}$ & df & $\mathrm{F}$ & $\mathrm{p}$ \\
\hline \multirow{3}{*}{$\begin{array}{l}\text { Delayed post-test } \\
\text { (Word Recognition) }\end{array}$} & Semantic Set & 18 & 5.06 & 1.26 & \multirow{3}{*}{$\begin{array}{c}2 \\
34\end{array}$} & \multirow{3}{*}{1.755} & \multirow{3}{*}{0.183} \\
\hline & Thematic Set & 18 & 5.17 & 1.15 & & & \\
\hline & Unrelated Set & 18 & 5.67 & 0.59 & & & \\
\hline \multirow{3}{*}{$\begin{array}{l}\text { Delayed post-test } \\
\text { (Word Production) }\end{array}$} & Semantic Set & 18 & 1.39 & 1.09 & \multirow{3}{*}{$\begin{array}{c}2 \\
34\end{array}$} & \multirow{3}{*}{1.084} & \multirow{3}{*}{0.346} \\
\hline & Thematic Set & 18 & 2.08 & 1.83 & & & \\
\hline & Unrelated Set & 18 & 1.94 & 1.48 & & & \\
\hline
\end{tabular}

Maximum mean score $=6.00$

\section{DISCUSSION AND CONCLUSION}

The findings of this study indicate that presenting new L2 words in semantic, thematic or unrelated sets all resulted in very high rates of vocabulary gains in terms of EFL learners' receptive and productive knowledge of the target words. Within the current study, EFL learners were taught real L2 target words through pictorial flashcards, and they were provided with a number of meaningful encounters with these target words in sentential contexts, which were also supplemented with visual images. In these circumstances, all types of clustering words provided EFL learners with very effective recognition and production of the target vocabulary items not only immediately after the treatments but also three weeks later. The study results revealed no statistically significant difference between teaching words in semantic, thematic, or unrelated sets in a real classroom setting. In brief, the present study found no interfering effects of these groupings on EFL learners' acquisition of these words in real classroom atmosphere, especially when they were given opportunity to practice newly-learned words in a larger context and within a great deal of time.

The results of this study bring a new dimension to the recent research findings on the controversial issue of whether to teach L2 vocabulary in semantic, thematic or unrelated sets. It suggests that the way of grouping new L2 vocabulary items is not so important. Rather, how many words to teach in per class period and how to teach these lexical items may be much more crucial than the way of clustering them. On the one hand, setting a realistic goal on how much vocabulary should be taught to L2 learners is an important step in designing a well-planned vocabulary instruction program. Naturally, the size of words to be presented at a time depends on many factors such as the difficulty of the words, their similarity to L1 and the levels, needs, and interests of the learners. However, Schmitt (2000) recommends teaching an average of 10 new words in a 60-minute lesson. According to Gairns and Redman (1986), ideal vocabulary load is eight to twelve productive items in a 60-minute lesson. On the other hand, how to present and practice novel vocabulary items in L2 classroom is also more important than how these lexical items are clustered before teaching. Obviously, the quality of teaching relies on many different variables, and there is no best way of teaching L2 vocabulary which suits all kinds of situations. However, L2 teachers can take into consideration some practical guidelines suggested by the relevant L2 lexical research. The current study takes a few of these guidelines into account. These are as follows: using dual coding, exemplification of the concept the word refers to and providing a number of encounters with a word. 
First, dual coding means using both visuals and verbal linguistic elements together to convey the meaning of a target word (see Paivio, 1991; and Clark \& Paivio, 1991 for further information about the dual coding theory). Similarly, in this study, the target vocabulary items were presented to EFL learners through both pictorial flashcards and verbal linguistic elements. Second, providing L2 learners with effective examples related to the concept of the target word also facilitates learning the meaning of the given word. Nation (2001) states that "examples help bring a message alive" (p. 215). Likewise, the current study intends to provide EFL learners with sentential contexts so that they can easily conceptualize the meanings of target words in their minds. Third, knowing a word requires learning many aspects of that word such as spelling, pronunciation, meaning, and use. One encounter with a target word may not be sufficient for L2 learners even to learn only one meaning sense of the given word. Therefore, newly-learned L2 words should be repeated, recycled and practiced several times through a variety of exercises, tasks and activities. With this in mind, the present study, to a certain extent, tries to provide L2 learners with a number of encounters in different meaningful contexts so as to compare the effects of grouping new L2 words in semantic sets and unrelated sets.

There are many studies which attempted to compare the effects of clustering novel L2 words in different ways on the acquisition of these lexical items by L2 learners. However, most of these studies were carried out in strictly-controlled experimental conditions. As an example, the study by Wilcox and Medina (2013) provides the participants with only two seconds to learn each target word. In Ishii's (2015) study, the learners have to memories six new words in 45 seconds. Such kinds of studies can be claimed to deal with memorization, rather than learning. Therefore, it may not be appropriate to draw conclusions from such experimental conditions about learning L2 vocabulary in natural classroom atmosphere. Apart from being conducted in a laboratory-like setting, many studies select artificial words as the target vocabulary instead of using real L2 words in real classroom environment. In addition, most experimental studies present the target words in isolation. However, this study anticipates that practicing these words in a larger context and within a great deal of time may provide better learning or less confusion, thereby changing the study results.

Taking these weaknesses into account, the current study intends to compare three methods of clustering new L2 vocabulary items in a natural EFL high school classroom setting, and it supplies EFL learners with the opportunities to practice the real target vocabulary items in different meaningful contexts which were also supplemented by visual materials. The study findings reveal that semantic, thematic and unrelated grouping of new L2 words enhance EFL learners' acquisition of these lexical items when a meaningful learning environment is provided to these learners. Likewise, Bolger and Zapata (2011) find out that adding a story context to the target words may surmount much of the disadvantage attributed to presenting semantically related words at the same time. The study also concludes that there is no significant difference between the benefits of teaching new L2 words in semantic, thematic or unrelated sets, especially when these words are sufficiently practiced through visual materials and effective sample sentences. 


\section{IMPLICATIONS, LIMITATIONS AND SUGGESTIONS FOR FURTHER RESEARCH}

The current research has revealed some significant implications in terms of L2 vocabulary learning and teaching. First, the quality of L2 vocabulary instruction is more important than how vocabulary items are clustered. Second, visual materials deserve an indispensable role in almost all stages of $\mathrm{L} 2$ lexical instruction since they promote better learning and higher retention of vocabulary items. Third, apart from the explicit teaching of L2 vocabulary in isolation, EFL teachers should provide their students with opportunity to practice newly-learned words in greater context, such as effective example sentences, so that the students can easily conceptualize the meaning of these words in their minds. Fourth, novel L2 vocabulary items should be recycled and revised in a range of meaningful contexts through a variety of useful exercises, productive tasks and activities. All in all, while presenting L2 vocabulary to their students, EFL teachers should derive benefits from various effective techniques, rather than adopting only one approach in vocabulary instruction.

Taking the limitations of the present study into account, some recommendations can be made for further research. To start with, there is still a lack of real-classroom based research studies to compare the effects of semantic, thematic and unrelated clustering of new L2 words on EFL learner's acquisition of these items. Therefore, these research findings need to be verified through similar kinds of classroom-based studies. Second, the scope of the current study is limited in both the size of the participants and the number of target words. Therefore, conducting further studies with larger sample size and different vocabulary items will reveal greater certainty on these research findings. Third, it would be better to verify these research findings with different types of learners and with different age groups in that the present study is restricted with only EFL learners. Fourth, this study adds sentential contexts to the target words to be taught. Further research can focus on the practice of the target vocabulary items in larger contexts such as teaching L2 words while students are reading academic or literary texts. Finally, all the target words used in the study were concrete nouns, so an investigation into other parts of speech can also be the subject matter for further studies. 


\section{REFERENCES}

Aitchison, J. (1994). Words in the mind: An introduction to the mental lexicon. Oxford: Blackwell Publishers.

Al-Jabri, S. S. (2005). The effects of semantic and thematic clustering on learning English vocabulary by Saudi students. Unpublished Doctoral Dissertation. Indiana University of Pennsylvania, Indiana, PA.

Baddeley, A. (1990). Human memory. London: Lawrence Erlbaum Associates.

Baydar Ertopçu, F., İnci, H., Özbıçakçı Samur, S. \& Albayrak, Y. (2014). Yes You Can Student's Book A2.2. Ankara: MEB Yayınları.

Bolger, P., \& Zapata, G. (2011). Semantic categories and context in L2 vocabulary learning. Language Learning, 61 (2), 614-646.

Clark, J. M., \& Paivio, A. (1991). Dual coding theory and education. Educational Psychology Review, 3 (3), 149-210.

Cobb, T. (n.d.). Compleat lexical tutor. Retrieved from http://www.lextutor.ca/

Erten, İ. H., \& Tekin, M. (2008). Effects on vocabulary acquisition of presenting new words in semantic sets versus semantically unrelated sets. System, 36, 407422.

Finkbeiner, M., \& Nicol, J. (2003). Semantic category effects in second language word learning. Applied Psycholinguistics, 24, 369-383.

Gairns, R., \& Redman, S. (1986). Working with words. Cambridge: Cambridge University Press.

Graves, M. (2006). The vocabulary book: Learning and instruction. New York: Teachers College Press.

Hashemi, M. R., \& Gowdasiaei, F. (2005). An attribute-treatment interaction study: Lexical-set versus semantically-unrelated vocabulary instruction. RELC Journal, 36, 341-361.

Haycraft, J. (1993). An Introduction to English Language Teaching. Malaysia: Longman.

Hedge, T. (2000). Teaching and learning in the language classroom. New York: Oxford University Press.

Hippner-Page, T. (2000). Semantic clustering versus thematic clustering of English vocabulary words for second language instruction: Which method is more effective? Retrieved from ERIC database. (ED445550)

Hoshino, Y. (2010). The categorical facilitation effects on L2 vocabulary learning in a classroom. RELC Journal, 41, 301-312.

Ishii, T. (2013). Reexamining semantic clustering: Insight from memory models. Vocabulary Learning and Instruction, 2(1), 1-7.

Ishii, T. (2015) Semantic connection or visual connection: Investigating the true source of confusion. Language Teaching Research, 19 (6), 712-722.

McCarthy, M. (1990). Vocabulary. Oxford: Oxford University Press.

Mirjalali, F., Jabbari, A. A., \& Rezai, M. J. (2012). The effect of semantic and thematic clustering of words on Iranians vocabulary learn $\neg$ ing. American International Journal of Contemporary Research, 2 (2), 214-222. 
The effects of clustering new words in semantic, thematic or unrelated sets in teaching...

Nation, I. S. P. (2000). Learning vocabulary in lexical sets: Dangers and guidelines. TESOL Journal, 9,6-10.

Nation, I. S. P. (2001). Learning vocabulary in another language. Cambridge, England: Cambridge University Press.

Paivio, A. (1991) Dual coding theory: Retrospect and current status. Canadian Journal of Psychology - Revue Canadienne de Psychologie, 45 (3), 255-287.

Papathanasiou, E. (2009). An investigation of two ways of presenting vocabulary. ELT Journal, 63, 313-322.

Sarığlu, M. (2014). The use of mnemonic devices for minimizing cross-association in teaching vocabulary to primary school EFL learners. Unpublished Master's Thesis. Uludağ University, Bursa, Turkey.

Schmitt, N. (2000). Vocabulary in language teaching. Cambridge: Cambridge University Press.

Stahl, S. A., \& Nagy, W. E. (2006). Teaching word meanings. Mahwah, NJ: Erlbaum.

Tinkham, T. (1993). The effect of semantic clustering on the learning of second language vocabulary. System, 21, 371-380.

Tinkham, T. (1997). The effects of semantic and thematic clustering on the learning of second language vocabulary. Second Language Research, 13, 138-163.

Waring, R. (1997). The negative effects of learning words in semantic sets: A replication. System, 25, 261-274.

Wilcox, A. \& Medina, A. (2013). Effects of semantic and phonological clustering on L2 vocabulary acquisition among novice learners, System, 41, 1056-1069.

Wilkins, D. A. (1972). Linguistics and language teaching. Cambridge: Cambridge University Press. 


\section{GENIŞLETILMIŞ ÖZET}

\section{Giriş}

Kelime bilgisi ve kelime öğretimi yabancı dil eğitiminde önemli bir yer tutmaktadır çünkü kelimeler olmadan bir dilin var olması da düşünülemez. Kelime bilgisi bir dilde hem iletişimin sağlanması için hem de o dille ilgili yeterlilik düzeyinin ortaya konulması için hayati derecede önemlidir. Yabancı dil eğitiminde kelimelerin en etkili biçimde nasıl öğretilebileceği konusundaki tartışmalar hâlen devam etmektedir. Yeni kelimelerin anlamsal, tematik ya da bağlantısız gruplar hâlinde öğretilmesi konusu sürekli araştırılmakta ve bu üç gruplama yönteminden hangisinin daha etkili olduğu yönündeki tartışmalar devam etmektedir. Kelimelerin anlamsal gruplar hâlinde öğretilmesi ile kastedilen durum öğretilmek üzere seçilecek kelimelerin 'renkler', 'hayvanlar', 'mutfak aletleri' gibi anlamsal bir bütünlük içindeki gruplar hâlinde seçilmesidir. Tematik gruplandırmadan kastedilen durum ise seçilecek kelimelerin bir tema etrafinda birleşiyor olmasıdır; örneğin 'terzi, elbise, makas, iğne' kelimeleri 'dikiş' teması altında birleşmektedirler. Bağlantısız kelime gruplarından kastedilen ise seçilen kelimelerin herhangi bir anlamsal ya da tematik grupta toplanamamasıdır; örneğin 'gül, masa, ekmek, aslan, makas' kelimeleri bağlantısız bir grup oluşturmakta yani herhangi bir anlamsal ya da tematik gruplandırmaya ait olamamaktadırlar. Kelime öğretimi ile ilgili yapılan çeşitli çalışmalar bu üç gruplandırma yönteminin de ayrı ayrı etkisini ortaya koymuştur fakat hangi gruplandırma yönteminin diğerlerine göre daha etkili olduğu ve daha kalıcı öğrenmelere yol açtığı konusu hâlen tartışılmaktadır. Bu sebeple, bu çalışmanın amacı yabancı dil eğitiminde kelime öğretirken seçilecek kelimelerin anlamsal, tematik ya da bağlantısız gruplar hâlinde seçilmesi ve öğretilmesinin öğrenme üzerindeki etkisini ortaya çıkarmaktır. Çalışmada iki farklı araştırma sorusuna cevap aranmaktadır: (1) Yeni kelimelerin anlamsal, tematik ya da bağlantısız gruplar hâlinde öğretilmesinin İngilizceyi yabancı dil olarak öğrenen öğrencilerin yeni kelimeleri anlamasında ve kullanmasındaki etkisi nedir?; (2) Yeni kelimelerin anlamsal, tematik ya da bağlantısız gruplar hâlinde öğretilmesinin İngilizceyi yabanc1 dil olarak öğrenen öğrencilerin öğretim sonrası ve ertelenmiş anlama ve üretme testlerindeki performanslarına herhangi bir etkisi var mıdır?

\section{Yöntem}

Bu çalışmaya İngilizceyi yabancı dil olarak öğrenmekte olan 18 Türk öğrenci katılmıştır. Katılımcılar on birinci sınıfa devam etmekte olan lise öğrencileridirler ve İngilizce düzeyleri A2 CEFR (Common European Framework of Reference for Languages) olarak belirlenmiştir. Çalışma ile ilgili uygulamalar katılımcıların doğal sınıf ortamlarında gerçekleştirilmiştir ve uygulamaları öğrencilerin İngilizce öğretmeni yapmıştır. Çalışmanın başlangıcında 23 olan katılımcı sayısı ön test sonuçlarına göre 18'e düşmüştür çünkü yapılan ön-teste göre beş potansiyel katılımcının öğretilecek olan bazı kelimeleri zaten bildiği ortaya çıkmıştır. Ön-testten sıfır puan alan 18 katılımcı ile araştırma tamamlanmıştır.

Çalışmada katılımcılara öğretilmek üzere 18 adet kelime seçilmiştir. Bu kelimelerin altı tanesi anlamsal olarak gruplandirılan kelimeler (kitchen utensils: grater, funnel, ladle, whisk, tray, jug), altı tanesi "kurbağa (frog)" teması altında gruplandırılan kelimeler (pond, speckle, leap, croak, log, beetle) ve altı tanesi de bağlantısız kelime grubu (tulip, sledge, pliers, eel, okra, stool) olarak seçilmişlerdir. Ayrıca kelimeler belirlenirken 
The effects of clustering new words in semantic, thematic or unrelated sets in teaching...

kullanım sıklığı, harf sayısı, hece sayısı, kelime türü gibi değişkenler de göz önünde bulundurulmuş ve bu değişkenler açısından birbirine yakın olan kelimeler seçilmiştir.

Çalışmada üç ayrı uygulama yapılmış ve her bir uygulamada katılımcılara üç farklı gruplama biçiminden birisi kullanılarak kelimeler öğretilmiştir. Uygulamalar sırasında öğretilen kelimeler dışındaki tüm faktörlerin (kullanılan materyaller, öğretme süresi, öğretme biçimi, teknoloji kullanımı) eşit olmasına özen gösterilmiştir. Her bir uygulama sonrasında katılımcılara o uygulamada öğretilen kelimelerle ilgili kelime anlama ve kelime kullanma testleri (immediate post-test) verilmiştir. Ayrıca her bir uygulamadan üç hafta sonra yine o uygulamada öğretilen kelimelerle ilgili kelime anlama ve kelime kullanma testleri (delayed post-test) verilmiştir.

Çalışmanın verileri 2016-2017 öğretim yılının güz döneminde toplanmıştır. Kelime üretmeye yönelik olarak verilen testlerin puanlandırılmasında tam olarak doğru üretilen her bir kelime için 1 puan, yazım hatası ile üretilen fakat doğru olan her bir kelime için 0.5 puan verilmiştir. Kelime anlamaya yönelik olarak yapılan testlerde ise her bir doğru cevap için 1 puan verilmiştir. Tüm testlerde alınabilecek en yükssek puan 6 olmuştur. Verilerin analizinde önce tüm testler için betimsel istatistikler (ortalama ve standart sapma) hesaplanmış daha sonra da kelime gruplandırma türünün test sonuçları üzerindeki etkisini belirleyebilmek için ANOVA (one-way repeated measures) testleri uygulanmış, ANOVA sonuçlarına göre anlamlı fark bulunduğunda ise Bonferroni tekniği kullanılarak ikili karşılaştırmalar yapılmıştır.

\section{Bulgular}

Araştırmanın sonuçlarına göre her üç gruplama türünde de yeni kelimeler katılımcılar tarafından öğrenilmiştir. Uygulama öncesinde yapılan ön-test sonuçlarına göre katılımcılar kendilerine öğretilecek kelimeleri bilmiyorlardı fakat her üç uygulama sonrasında da yapılan testlere göre katılımcıların yeni kelimeleri büyük oranda öğrendikleri belirlenmiştir. Anlamsal gruplar hâlinde kelime öğretimi uygulamasından sonra yapılan kelime anlama testinden alınan ortalama puan 5.94, kelime üretim testinden alınan ortalama puan ise 5.53 olarak bulunmuştur. Alınabilecek en yüksek puanın 6 olduğu düşünüldüğünde her iki testten de oldukça yüksek puanlar alındığı söylenebilir. Benzer sonuçlar tematik gruplandırma ya da bağlantısız gruplandırma ile kelime öğretimi uygulaması sonrasında yapılan testlerde de bulunmuş, her uygulama sonrasında öğrencilerin hem kelime anlama hem de kelime üretme testlerinden yüksek puanlar aldıkları gözlemlenmiştir. Diğer taraftan, kelime gruplandırma türünün test sonuçları üzerinde bir etkisi olup olmadığı incelendiğinde ise herhangi bir anlamlı fark görülememiştir. Diğer bir deyişle, yeni kelimelerin anlamsal, tematik ya da bağlantısız gruplar hâlinde öğretilmesi durumlarından herhangi birisinin diğerlerine göre daha etkili olduğuna dair anlamlı bir sonuca ulaşılamamıştır. Örneğin, her üç kelime grubuna göre yapılan üç farklı uygulamanın hemen sonrasında verilen kelime anlama testi sonuçlarına göre anlamsal gruplandırma ile kelime öğretimi sonrası ortalama test puanı 5.94, tematik gruplandırma ile kelime öğretimi sonrası ortalama test puanı 6.00 , bağlantısız gruplandırma ile kelime öğretimi sonrası ortalama test puanı ise 5.89 olarak bulunmuş, bu üç puan arasında istatistiksel olarak anlamlı bir farka rastlanamamıştır. 


\section{Sonuç}

Yabancı dil eğitiminde kelime öğretirken seçilecek kelimelerin anlamsal, tematik ya da bağlantısız gruplar hâlinde seçilmesi ve öğretilmesinin öğrenme üzerindeki etkisini araştıran bu çalışmanın sonuçlarına göre her üç gruplandırma türüyle yapılan öğretim sonrasında öğrencilerin öğretilmeye çalışılan kelimelerin büyük çoğunluğunu öğrendikleri bulunmuştur. Diğer bir deyişle, yabancı dilde kelime öğretiminde üç farklı kelime gruplandırma yönteminden herhangi birisinin diğerlerinden daha etkili olduğuna dair bir sonuca ulaşılamamıştır. Bu sonuçtan hareketle, yabancı dilde kelime öğretiminde öğretilecek kelimelerin gruplandırılma biçiminden çok öğretilecek kelimelerin sayısının ya da kullanılan öğretme tekniklerinin niteliğinin daha belirleyici olabileceği çıkarımına ulaşılabilir. Araştırmanın son bölümünde bu çıkarımla ilgili fikirler ilgili literatür ışı̆̆ında tartışılmış ve sınıf içi uygulamalarına yönelik çeşitli tavsiyelere yer verilmiştir. Bu tavsiyelerde, kelime öğretim yöntemlerinin niteliği, kelime öğretimi sırasında görsel malzeme kullanımının önemi, öğretilen kelimelerin gerçek hayat benzeri durumlarda kullanılabilmesi için öğrencilere firsat verebilecek aktivitelerin hazırlanması ve öğretilen kelimelerin sık sık tekrarının sağlanması gibi fikirler ön plana çıkmıştır. Ayrıca yine son kısımda, bu çalışmanın yöntemi ve bulguları göz önüne alınarak bundan sonra kelime öğretimi ile ilgili yapılabilecek diğer çalışmalar için de çeşitli tavsiyelere yer verilmiştir. 